TITLE:

\title{
Distribution and Bed Structure of the Two Intertidal Mussels, Septifer virgatus (Wiegmann) and Hormomya mutabilis (Gould)
}

\author{
AUTHOR(S): \\ Iwasaki, Keiji
}

\section{CITATION:}

Iwasaki, Keiji. Distribution and Bed Structure of the Two Intertidal Mussels, Septifer virgatus (Wiegmann) and Hormomya mutabilis (Gould). PUBLICATIONS OF THE SETO MARINE BIOLOGICAL LABORATORY 1994, 36(4): 223-247

\section{ISSUE DATE:}

1994-11-15

URL:

http://hdl.handle.net/2433/176237

RIGHT: 


\title{
Distribution and Bed Structure of the Two Intertidal Mussels, Septifer virgatus (Wiegmann) and Hormomya mutabilis (Gould)
}

\author{
KeIjI IWASAKI \\ Department of Zoology, Facuity of Science, Kyoto University, \\ Sakyo, Kyoto 606-01, Japan
}

With Text-figures $1-11$ and Tables $1-3$

\begin{abstract}
The distribution and bed structure of the two mytilid bivalves, Septifer virgatus and Hormomya mutabilis, were investigated on rocky intertidal shores at Shirahama, Wakayama Prefecture, Japan. $S$. virgatus inhabited more wave-exposed shores than $H$. mutabilis. On rock slopes receiving moderate wave action, both species formed contiguous mussel beds vertically, the former occurring from the upper to mid intertidal zones and the latter in the lower zone. Juvenile $H$. mutabilis were found abundantly in the mussel beds of both species, attaching to byssal threads or to the shell surface of other musscls. Very few $S$. virgatus of all sizes were found in the $H$. mutabilis bed. The amount of byssal thread material and the drag force required to detach mussels were both greater in $H$. mutabilis than in $S$. virgatus. Individual variation in shell shape was greater in $H$. mutabilis than in $S$. virgalus. A much larger amount of sediment accumulated in $H$. mutabilis beds than in $S$. virgatus beds. This may reflect the denser byssal threads network and more tightly packed individuals in the $H$. mutabilis beds. Factors determining the lower distribution limit of $S$. virgatus and the upper limit of $H$. mutabilis are discussed in relation to the differences in morphology and bed structure of the mussels.
\end{abstract}

Key words: amount of byssal threads, distribution, Hormomya mutabilis, mussel bed structure, sedimentation, Sepifer virgatus, shell shape plasticity

\section{Introduction}

The extensive research into organization of intertidal and subtidal communities has revealed that mytilid bivalves play dominant roles in competition among sessile organisms (reviews by Suchanek, 1985; Seed \& Suchanek, 1992). The dominance is attributable to the ability to overgrow most organisms other than foliose algae (Paine, 1974; Witman \& Suchanek, 1984; Witman, 1987) by forming dense aggregations with their byssal threads. (Jackson, 1983; Bertness \& Grosholz, 1986; Suchanek, 1985). Many investigators have clarified various aspects of mussel ecology (reviews by Seed, 1976; Suchanek, 1985; Hosomi, 1989; Seed \& Suchanek, 1992), and there have been several studies in which interspecific interactions between two or more coexisting mussel species have been analysed (Hoshiai, 1961, 1964; Harger, 1968, 1970a, b, c, 1972a, b; Harger \& Landenberger, 1971; Kennedy, 1976; Suchanek, 1978, 1981; Safriel \& Sasson-Frostig, 1988; Branch \& Barkai, 1988; Barkai \& Branch, 1989)

The interspecific interactions between mussels have been examined exclusively from the viewpoint of competition, which results in either the competitive exclusion of one by another or coexistence mediated by physical disturbance or predation. The

Publ. Seto Mar. Biol. Lab., 36(4), 223-247, 1994.

(Article 17) 
competitive mechanisms demonstrated or suggested are 1) the crushing of the thinner valves of inferiors by superiors with robust valves (Harger, 1968, 1970c, 1972b; Suchanek, 1978), 2) the overgrowing of inferiors by superiors capable of climbing over the former (Hoshiai, 1961, 1964; Harger, 1968, 1970c, 1972b; Suchanek, 1978), 3) difference in the tolerance of smothering by siltation in mussel beds (Branch \& Barkai, 1988; Barkai \& Branch, 1989), and 4) interference by adult mussels with recruits of heterospecifics (Safriel \& Sasson-Frostig, 1988). These mechanisms also limit vertical distribution of two potentially coexisting mussel species (Hoshiai, 1958, 1961, 1964; Suchanek, 1978). These studies suggest that research into mussel bed structure (size distribution, density, attachment location, and quality and quantity of byssal threads) and mussel behaviour in the beds is essential to analyse the factors affecting mussel settlement, growth and mortality within the beds (Harger, 1968; Okamura, 1986). In the context of interspecific interactions, however, there have been very few studies which analyse interspecific differences in mussel bed structure (Harger, 1968, 1970a, b, 1972b).

The present study investigates the distribution and bed structure of two intertidal rocky shore mussels, Septifer virgatus (Wiegmann) and Hormomya mutabilis (Gould). On some shores around the Seto Marine Biological Laboratory of Kyoto University in Wakayama Prefecture, Japan, the two species occur together on a rocky reef, forming vertically contiguous mussel beds (Ohsako et al., 1981, 1982a, b). Factors determining the lower distribution limit of the upper inhabitant $S$. virgatus and the upper limit of the lower inhabitant $H$. mutabilis are then discussed in relation to interspecfic differences in morphological features of the mussels and their bed structure.

\section{Study Sites and Methods}

Horizontal distribution

Occurrence of $S$. virgatus and $H$. mutabilis was investigated on rocky shores extending for about $4.6 \mathrm{~km}$ around the Seto Marine Biological Laboratory $\left(33^{\circ} 42^{\prime} \mathrm{N}\right.$, $135^{\circ} 21^{\prime} \mathrm{E}$ ). At the lowest tide of the year (low tide on the night of December 3-4, 1982), the positions of mussel beds (larger than about $1 \mathrm{~m}^{2}$, hereafter referred to as Septifer bed and Hormomya bed, respectively) and mussel clumps (smaller than 1 $\mathrm{m}^{2}$ ) were recorded on a map of the area (Fig. 1).

Vertical distribution

To compare vertical distribution of the two mussel species among sites with different fauna, flora and wave exposure, three study sites, $\mathrm{A}, \mathrm{B}$ and $\mathrm{C}$, were selected on rock slopes with similar inclination $\left(9^{\circ}\right.$ at site $A, 5^{\circ}$ at site $B$ and $4^{\circ}$ at site $\left.\mathrm{C}\right)$. All the sites faced the west (Fig. 1). Site A was located at the most wave-exposed part of the northern half of Kanayama Bay and appeared to receive intense wave action. The wave action at site $B$ seemed to be weaker than that at site $A$ and was stronger than that at site C (Ohsako et al., 1981).

A cross-shore transect was established at each study site. Transects of the sites B and $\mathrm{C}$ are identical with the lines $\mathrm{A}$ and $\mathrm{B}$ in Ohsako et al. (1981, 1982a, b). Along 


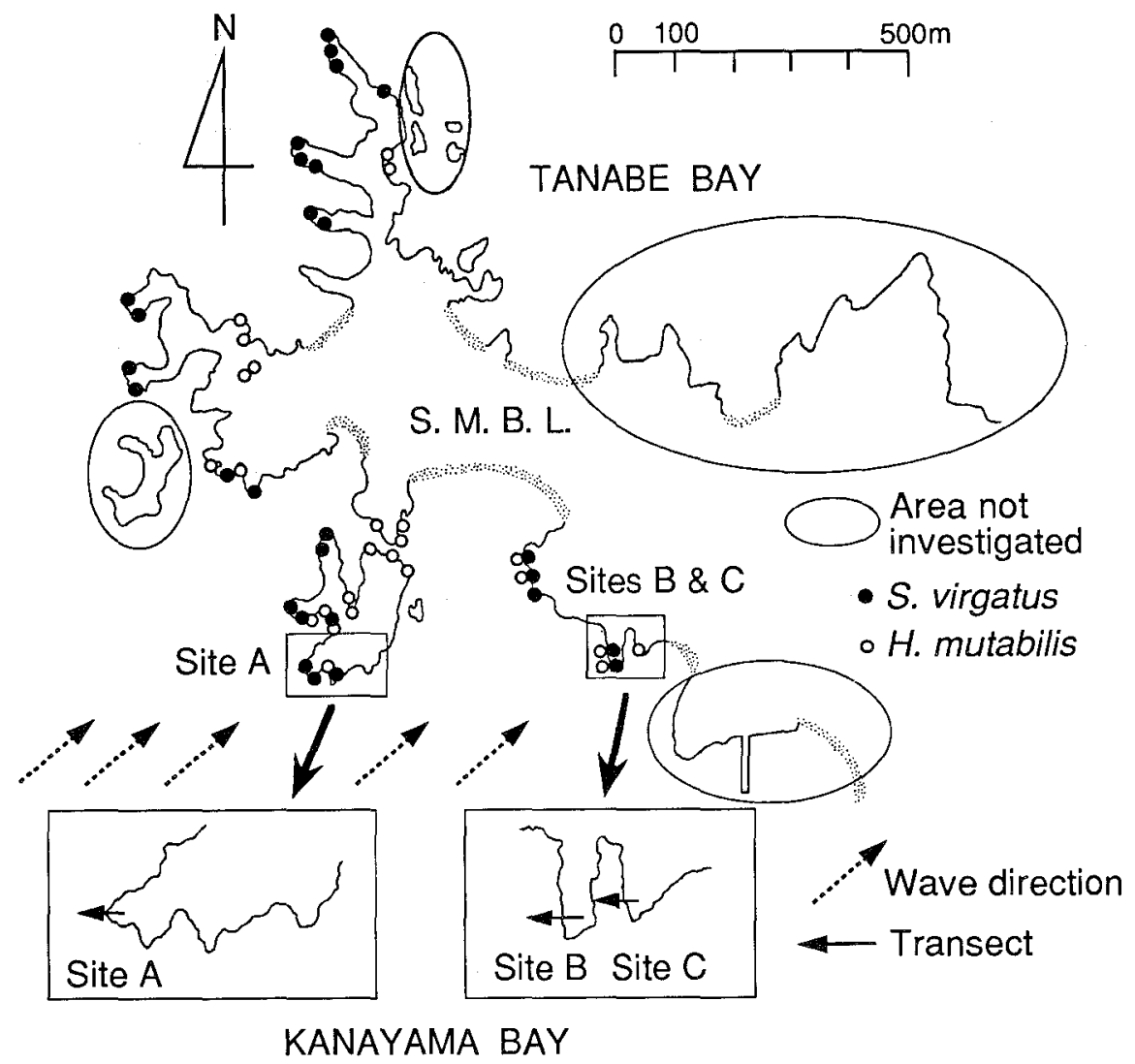

Fig. 1. Map of the study sites (Sites A, B, and G) and distribution of two mussel species (December 1982) around the Seto Marine Biological Laboratory (S.M.B.L.). Solid lines and dotted areas represent rocky and sandy shores, respectively. Each circle indicates the presence of a mussle bed or an assembly of mussel clumps.

the transects, numbers of sessile animals and percentage cover of macroalgae within a $10 \times 10 \mathrm{~cm}^{2}$ quadrat (hereafter referred to as a transect quadrat) were recorded for every $10 \mathrm{~cm}$ interval. The small barnacle Chthamalus challengeri Hoek was counted for ten small quadrats of $1 \mathrm{~cm}^{2}$ within the transect quadrat. The survey was conducted in April 1982 for site B, May 1982 for site G and December 1982 for site A. No organisms were scraped off the substratum in this transect census. Mean densities $/ 100 \mathrm{~cm}^{2}$ of the sessile animals and mean algal cover were calculated for every $10 \mathrm{~cm}$ interval of tide level (Fig. 3) using the values from this transect census. Organisms other than mussels, which attached to the mussel valves, were excluded in the calculation. Shore heights along the transects were measured by levelling, and the tide levels were determined from tide tables. Shore height is hereafter expressed in $\mathrm{cm}$ preceded by + or - , which indicates above or below mean tide level (MTL). 
Mussel bed structure at site B

Mussel bed structure was analysed at site B which was inhabited by both species.

Size distribution

At about $+35 \mathrm{~cm}$ and $-35 \mathrm{~cm}$, which corresponded approximately to the mid levels of Septifer and Hormomya beds respectively, mussels within two quadrats of $5 \times 10$ $\mathrm{cm}^{2}$ were scraped off with a small shovel every month from April 1982 to April 1983 (hereafter referred to as a scraping quadrat). Species identification was difficult for mussels smaller than $1 \mathrm{~mm}$ in shell length. Most mussels larger than $1 \mathrm{~mm}$ in length were left on a sieve with $0.5 \mathrm{~mm}$ mesh openings, while those smaller than this size were not. Accordingly, all the mussels left on the sieve were counted, and their shell lengths were measured using a slide caliper or micrometer under a microscope. Mussels of both species smaller than $10 \mathrm{~mm}, 10$ to $20 \mathrm{~mm}$ and larger than $20 \mathrm{~mm}$ in shell length are herafter referred to as juvenile, small, and large mussels, respectively.

To examine vertical change in the size distribution of mussels (Fig. 4), mussel sampling was conducted twice at four levels of the Septifer bed $(+65 \mathrm{~cm},+38 \mathrm{~cm}$, $+9 \mathrm{~cm}$ and $-6 \mathrm{~cm})$ and at two levels of the Hormomya bed $(-29 \mathrm{~cm}$ and $-56 \mathrm{~cm})$ in April 1982. In April 1992, mussel sampling was made after marking visible mussels with white paint. Four samples were taken at each mid level of the mussel beds using a $5 \times 10 \mathrm{~cm}^{2}$ quadrat. Then the shell length range of visible mussels exposed at the surface of the mussel beds was compared between the two species (Table 2).

Individual variation in shell shape

To detect interspecific difference of variation in shell morphology (Table 3), shell heights and shell widths (terminology according to Seed, 1968) of mussels collected by monthly sampling from July 1982 to April 1983 were measured. Fifty mussels of each species with 10-30 mm shell length were selected from each sample, and regressions of their shell heights and shell widths to shell lengths were calculated. Variance of the samples in the regression was then calculated for each species, and mean variance was compared between the two species.

By this procedure, the degree of individual variation in shell shape was examined.

\section{Attachment locations}

When the mussels attached to other individuals were detached for measuring shell length in the laboratory, the location where they attached their byssal threads was recorded from May 1982 onward according to the following criteria (Fig. 2): upper shell surface of another mussel (Upper shell surface in Fig. 2), lower shell surface of another mussel (Lower shell surface), byssal threads of another mussel attaching to the upper shell surface of a third mussel (Upper byssus), byssal threads of another mussel attaching to the lower shell surface of a third mussel or to the rock surface (Lower byssus), entangled in byssal threads of large mussels (Entangled with byssus) and unknown (single mussels which were detached from other mussels during collection in the field). Since byssal threads of large mussels were mingled 


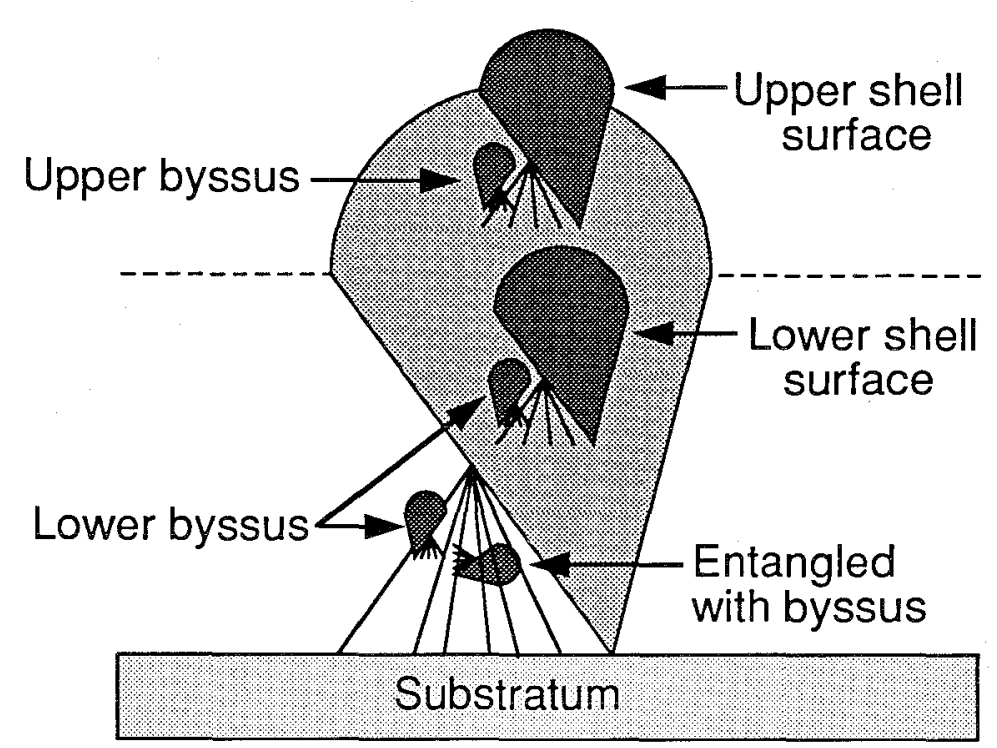

Fig. 2. Schematic representation of attachment locations of mussels within mussel beds.

with each other, the large mussels attached directly to the rock surface could not be distinguished readily from those attached to byssal threads of other mussels. Accordingly, all these large mussels were counted as "Lower byssus".

Amount of sediment

At the monthly sampling from April 1982 to April 1983, sediment such as sand, silt, mud and broken shell pieces among mussels and among byssal threads was also collected. The sediment was dried under the sun for at least two days and, after sifting out broken shell pieces through a sieve with $1 \mathrm{~mm}$ mesh openings, was weighed to the nearest tenth of a $\mathrm{mg}$. Inclination of mussel beds was considered to affect the amount of sediment within the beds. Accordingly, the inclination at site $\mathrm{B}$ was measured in April 1982 using a portable clinometer. A plastic board of $20 \times 20$ $\mathrm{cm}^{2}$ was haphazardly tossed down onto the beds, and the clinometer was placed on the board. Then the slope was noted accurate to $0.1^{\circ}$. This measurement was repeated twenty times in each mussel bed.

Number of byssal threads and force required to detach mussels

The number of byssal threads of mussels was compared beween the two species. Twenty two mussels (5-30 $\mathrm{mm}$ in shell length) of each species, with intact bundles of byssal threads, were selected from the specimens collected by scraping at site B in September 1982. The total number of byssal threads was counted for each mussel and the diameter of 15 randomly selected byssal threads was measured under a microscope. September is the month when typhoons attack middle Japan most frequently. It is believed that the attaching strength of mussels increases with 
increasing byssal threads (references given in "Discussion"). Price (1982) reports that the attaching strength of Mytilus edulis increased in the stormy season. Thus in September the interspecific difference in the number of byssal threads is expected to be greater than that in other months.

The force required to detach mussels was measured at about the mid level of mussel beds of both species in June 1993. A "crocodile" clip was used to grip a mussel and the force was recorded on a spring scale fixed to the clip as the mussel was detached. The length, height and width of the shells of the detached mussels were measured. Regressions of the force against approximate shell size (=shell length $\times$ shell height) were analysed and compared between the species.

Percentage of algal cover on the Hormomya bed at site B

Several foliose algae were growing on the Hormomya bed at site $\mathrm{B}$ in winter and spring. The algal cover was measured monthly from April 1982 to April 1983. A $20 \times 20 \mathrm{~cm}^{2}$ quadrat was haphazardly tossed down onto the mussel bed and the algae within the quadrat were recorded on a photograph. This was repeated at least eight times. Then a transparent sheet with 300 dot marks was placed over each photograph and the marks that fell over the spots of algal gtowths were counted. The percentage cover was determined as the percentage of the mean value of the counts to the total number of marks $(300)$.

\section{Statistical analyses}

Intra- and interspecific differences in the mean density of mussels (Table 1), the mean percentage of mussels exposed outside the mussel beds (Table 2), the mean inclination of the beds, and the variance from estimated regression lines of shell height and width to length (Table 3) were examined by one-way ANOVA. Values in percentage or proportion were transformed into arcsine. If the variance was not equal between the samples, a Mann-Whitney $U$ test was conducted. When the sample size exceeded 20 or when the tied values occurred across the samples in this non-parametric test, the ts value (Sokal \& Rohlf, 1981) was calculated (Table 1). The amount of sediment and attachment locations of individual mussels within the mussel beds were compared beween Septifer and Hormomya beds by Wilcoxon's signed rank test, because they appeared to show seasonal change. In the calculation, the larger of two values taken from monthly samples of the Septifer bed was paired with the larger one of two values from the Hormomya bed, and the lowers of the two values from each bed were also paired.

\section{Results}

Horizontal distribution

Septifer beds were found on all the exposed promontories around the Seto Marine Biological Laboratory (Fig. 1). H. mutabilis inhabited more sheltered rock slopes than $S$. virgatus (Fig. 1). Four rock slopes including site B had mussel beds of both species which were vertically contiguous. 
Vertical distribution

Most of the upper part of the transect at site A was covered by the barnacle C. challengeri (Fig. 3). S. virgatus were found at most of the tide levels surveyed, from $+80 \mathrm{~cm}$ down to $-60 \mathrm{~cm}$. The density of $S$. virgatus attained a maximum of $96 / 100$ $\mathrm{cm}^{2}$ at about mean tide level. Two barnacle species, Tetraclita squamosa japonica Pilsbry and Balanus volcano Pilsbry, inhabited mid and lower tide levels, respectively, with a density less than 25 per $100 \mathrm{~cm}^{2}$. Percentage cover of algae such as Sargassum thumbergii (Mertens) O. Kuntze, Hizikia fusiforme (Harvey) Okamura and Corallina pilulifera Postels et Ruprecht increased downwards in the lower half of the transect. The density of $H$. mutabilis was extremely low and not shown.

Both mussel species inhabited site $\mathbf{B}$, forming zonal mussel beds almost coniguous vertically. The Septifer bed extended from the highest part of the transect down to ca. $-25 \mathrm{~cm}$, the lower limit being $35 \mathrm{~cm}$ higher than that at site A. From +50 to $+30 \mathrm{~cm}$ on the transect, very few sessile organisms attached to the substratum because a large bare patch with an area of ca. $1 \mathrm{~m}^{2}$ occurred in the mussel bed. The Septifer bed was replaced by the Hormomya bed at about $-20 \mathrm{~cm}$, with a narrow overlapping range. The distribution of both species seems to be virtually exclusive. The mean density of $S$. virgatus on the transect from +30 to $-20 \mathrm{~cm}$ was significantly higher than that of $H$. mutabilis in the Hormomya bed (Table 1). The

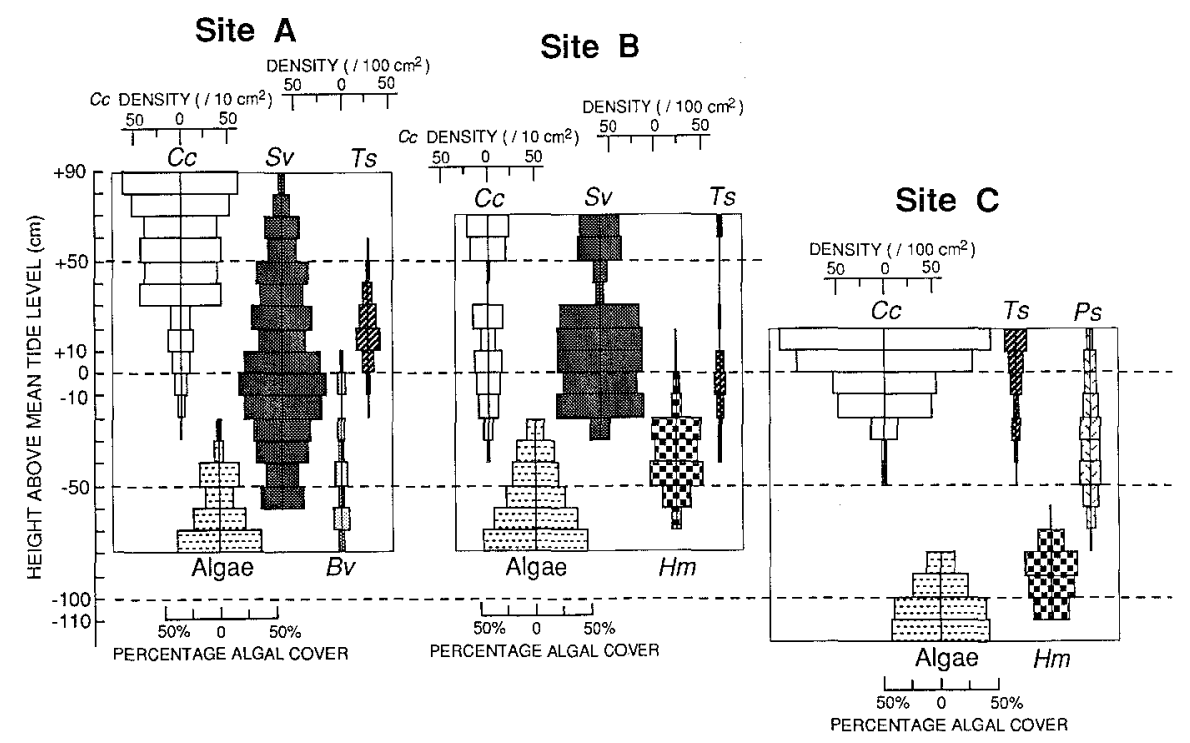

Fig. 3. Vertical distribution of intertidal organisms on the transects of three study sites. Cc: Chthamalus challengeri, Sv: Septifer virgatus, Bv: Balanus valcano, Ts: Tetraclita squamosa japonica, Hm: Hormomya mutabilis, Ps: Patelloida saccharina lanx. The vertical line of a rectangle for each study site indicates the tidal range of a transect. Note that the density scales for $C$. challengeri $\left(C_{c}\right)$ at sites $\mathrm{A}$ and $\mathrm{B}$ are different from those for the other animals at sites A-C and C. challengeri at site C. 
Table 1. Densities (mean $\pm \mathrm{SD}, / 50 \mathrm{~cm}^{2}$ ) of $S$. virgatus and $H$. mutabilis in their respective mussel beds. F: result of one-way ANOVA (when the variances were equal), ts: result of Mann-Whitney $U$ test (when the variances were not equal. Ties occurred across both samples, and sample sizes were larger than 20.). Data from a transect census from +30 to $-20 \mathrm{~cm}$ level for $S$. virgatus and from -25 to $-50 \mathrm{~cm}$ level for $H$. mulabilis in April 1982 and a scraping census every month from April 1982 to April 1983. df: degrees of freedom.

\begin{tabular}{lccccc}
\hline Kind of sampling & $\begin{array}{c}\text { Shell length } \\
\text { range }(\mathrm{mm})\end{array}$ & S. virgatus & H. mutabilis & $\mathbf{F}_{\text {(df) }}$ & $\mathrm{t}_{\mathrm{s(df)}}$ \\
\hline Transect & - & $45.3 \pm 10.0$ & $24.9 \pm 7.3$ & $91.81_{(1,72)}{ }^{* *}$ & - \\
Scraping & $\geq 10$ & $71.0 \pm 19.2$ & $69.2 \pm 13.5$ & $3.66_{(\mathbf{1 , 5 0 )}}^{\mathbf{n s}}$ & - \\
Scraping & $\geq 20$ & $30.4 \pm 5.4$ & $20.3 \pm 8.3$ & - & $3.99_{(50)}^{* *}$ \\
\hline
\end{tabular}

**: significant at $1 \%$ level, ns: not significant at $5 \%$ level.

density of $H$. mutabilis gradually decreased downwards, while percentage cover of some foliose algae such as Hizikia fusiforme, Corallina pilulifera and Gigartina intermedia Suringer increased downwards.

At site $\mathrm{C}$ where $S$. virgatus did not occur, most of the upper part of the transect was covered by $C$. challengeri. From mid tide level down to $-50 \mathrm{~cm}$, an acmaeid limpet Patelloida saccharina lanx (Reeve) dominated on the rock surface. The upper distribution limit of $H$. mutabilis was about $-60 \mathrm{~cm}, 40 \mathrm{~cm}$ lower than that of site $\mathbf{B}$.

Size distribution at site B

Juvenile $S$. virgatus were found abundantly in the samples obtained at all four levels in the Septifer bed in April 1982 (Fig. 4a). At two levels in the Hormomya bed, very few juvenile $S$. virgatus were collected and no adults (Fig. 4a). The density of the juveniles at the mid level of the Septifer bed was more or less constant from April to August, and decreased towards March 1983 (Fig. 5). However, the density of small and large $S$. virgatus did not show a noticeable seasonal change. At the mid level of the Hormomya bed, very few juvenile and no small nor large $S$. virgatus occurred throughout the year (Fig. 5).

Juvenile $H$. mutabilis were collected not only at two levels in the Hormomya bed but also at all four levels in the Septifer bed (Fig. 4b). H. mutabilis large than 18 $\mathrm{mm}$ occurred only in the $H$. mutabilis bed. Two distinct cohorts with peaks at about 10 and $20 \mathrm{~mm}$ in shell length were recognized (Fig. 4b). The size distribution of H. mutabilis did not exhibit a noticeable seasonal change either in the Septifer or in the Hormomya bed (Fig. 6) and juvenile H. mutabilis were found throughout the year. Mussels larger than $15 \mathrm{~mm}$ were collected only in the Hormomya bed throughout the period (Fig. 6). In the Hormomya bed, one or two distinct cohorts were recognized among the small and large $H$. mutabilis throughout the year.

Table 1 compares mean density per $50 \mathrm{~cm}^{2}$ between the two species and between different size groups of the same species. The densities in transect quadrats (that 

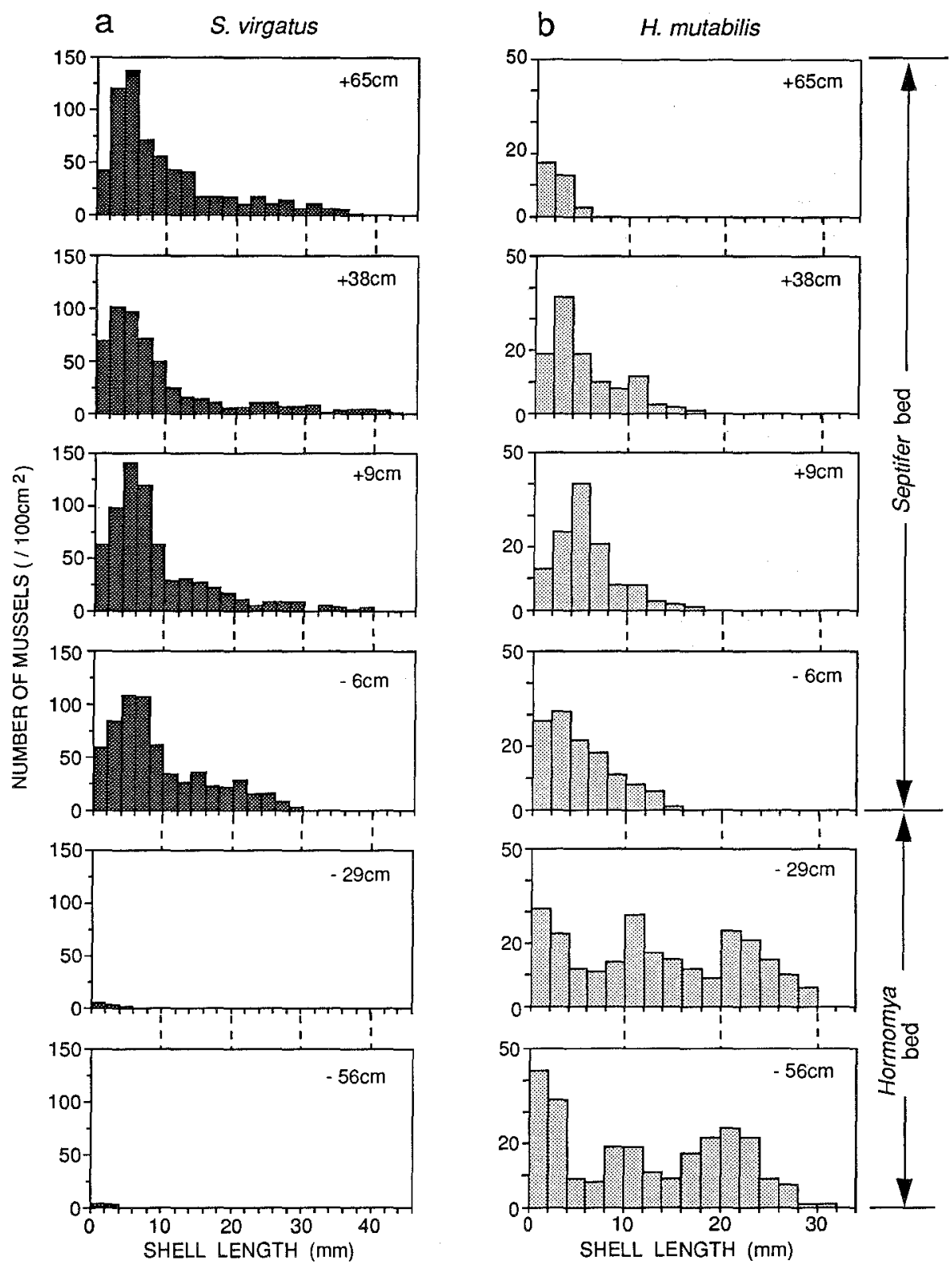

Fig. 4. Shell length distribution of $S$. virgatus (a) and $H$. mutabilis (b) collected from six levels at site B on April 1982. Note that scales of both abscissa and ordinate are different between the species. 


\section{S. virgatus}
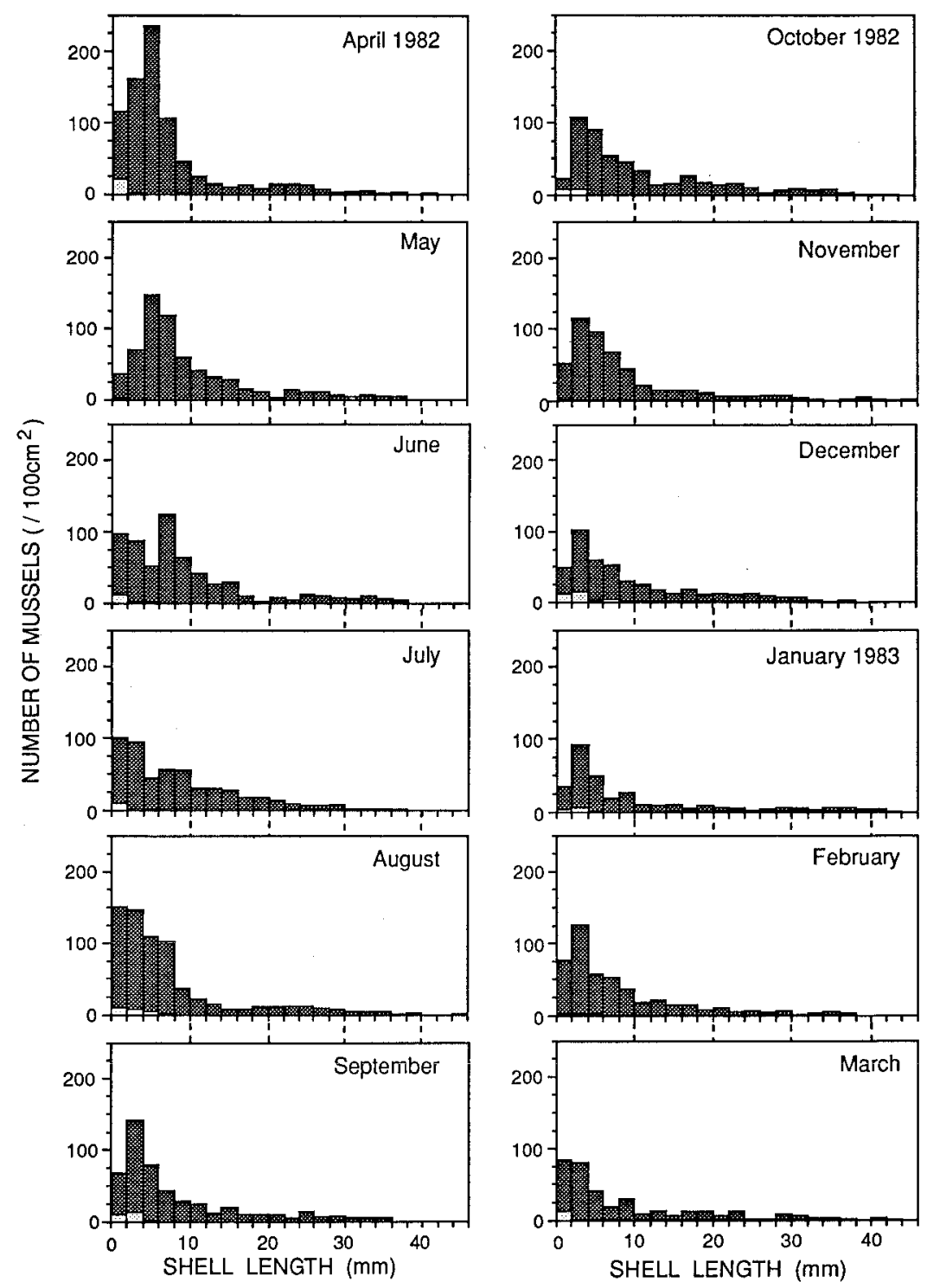

Fig. 5. Monthly change in the shell length distribution of $S$. virgatus collected at mid levels of the Seplifer bed (dark-shaded part) and the Hormomya bed (light-shaded part) at site $\mathrm{B}$. 


\section{H. mutabilis}
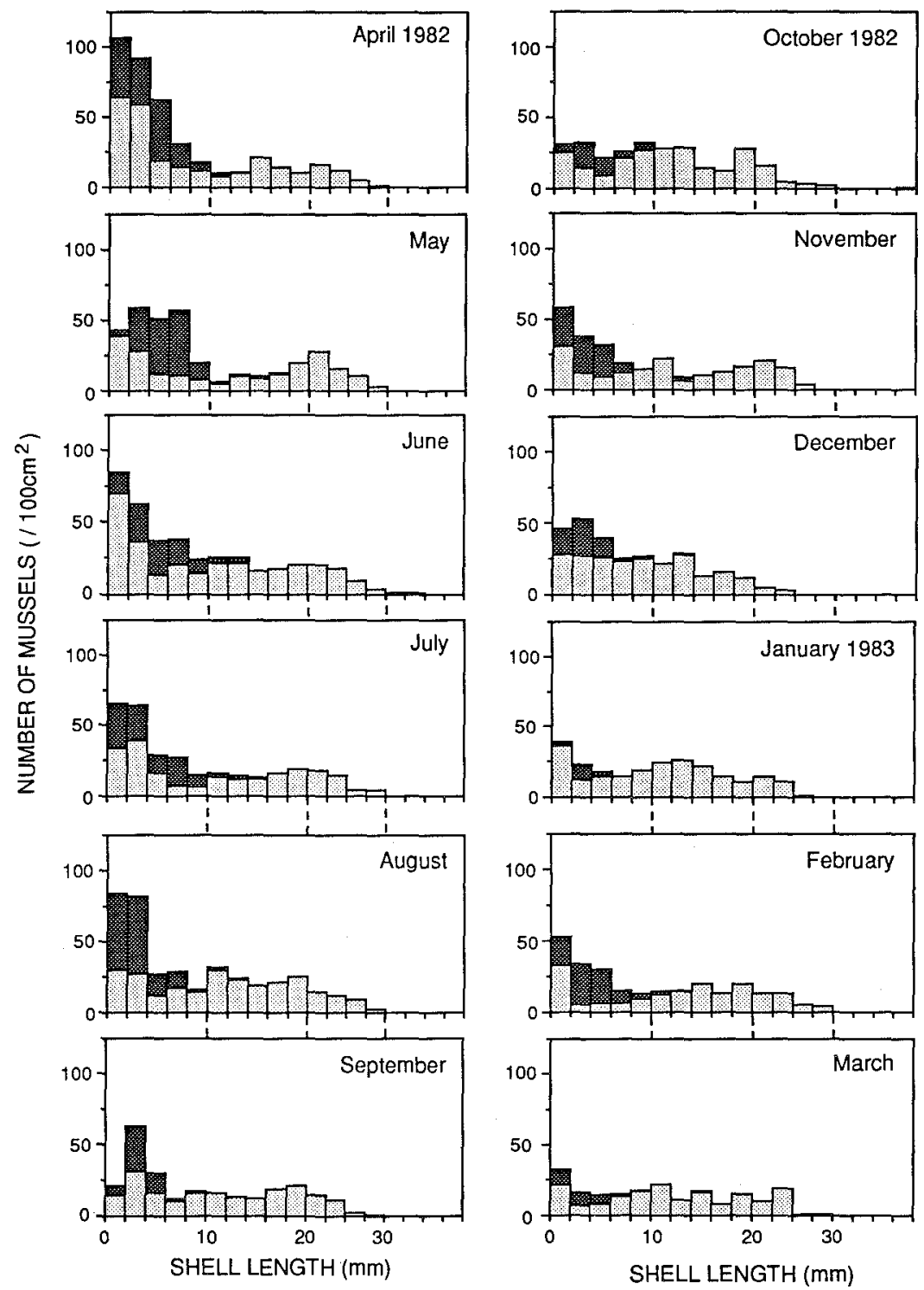

Fig. 6. Monthly change in the shell length distribution of $H$. mutabilis collected at about mid levels of the Septifer bed (dark-shaded part) and the Hormomya bed (light-shaded part) at site $B$. 
is, the density of mussels exposed at the surface of the mussel beds and therefore visible) were significantly higher in $S$. virgatus than in $H$. mutabilis. No significant difference was detected between the two species in small and large mussels in the scraping quadrat. The density of $S$. virgatus larger than $20 \mathrm{~mm}$ was significantly higher than that of $H$. mutabilis of the same size range. Evidently more mussels were exposed at the surface of the Septifer bed than of the Hormomya bed, though the densities of small and large mussels did not differ between the species.

The density of $S$. virgatus in the transect quadrat was significantly lower than that of small and large $S$. virgatus in the scraping quadrat (Mann-Whitney $U$ test: $\left.\mathrm{t}_{\mathrm{s}(66)}=5.575, \mathrm{p}<0.001\right)$. But the former density was significantly higher than that of large $S$. virgatus in the scraping quadrat (Mann-Whitney $U$ test: $t_{s(66)}=5.665$, $\mathrm{p}<0.001$ ). The same results were obtained for $H$. mutabilis (for small and large mussels, Mann-Whitney $U: t_{s(54)}=6.509, p<0.001$; for large mussels only, $F_{(1,56)}=$ $4.904, \mathrm{p}<0.05)$. The difference of density between the exposed individuals in the transect quadrat and the large individuals in the scraping quadrat was much greater in $S$. virgatus $\left(45.3-30.4=14.9\right.$ individuals $\left./ 50 \mathrm{~cm}^{2}\right)$ than in $H$. mutabilis $(24.9-20.3=4.6$ individuals $/ 50 \mathrm{~cm}^{2}$ ). In the Septifer bed also many small mussels were exposed at the surface. On the contrary, many mussels smaller than $20 \mathrm{~mm}$ were buried among large individuals inside the Hormomya bed and were invisible to the investigator.

Table 2 gives the mean percentages of exposed mussels in four scraping quadrats in April 1992. Most S. virgatus larger than $15 \mathrm{~mm}$ were exposed, and the percentage decreased with decreasing shell size. All $H$. mutabilis larger than $15 \mathrm{~mm}$ were also exposed. The percentages of exposed $H$. mutabilis in the size groups of $5-10 \mathrm{~mm}$ and 10-15 mm were significantly lower than those of $S$. virgatus in the same size groups. The proportion of mussels exposed in the two size groups was evidently greater in $S$. virgatus than in $H$. mutabilis. The results in Tables $1 \& 2$ reflect the difference of mussel bed structure between the species. The upper surface of the Septifer bed was more uneven and irregular than that of the Hormomya bed so that even juvenile and small mussels were exposed at the surface (see Fig. 11 for schematic representation of mussel bed). In the Hormomya bed, mussels larger than $15 \mathrm{~mm}$, which were recognized as a cohort in Figs. $4 \& 6$, were tightly packed so that small mussels were buried inside the bed.

Attachment locations of individual mussels

The attachment locations of juvenile $S$. virgatus differed considerably between the Septifer and Hormomya beds (Fig. 7). In the Septifer bed, more than half of them attached to the lower byssal threads of other mussels. About $15 \%$ were entagled with byssal threads of other individuals. Including mussels attaching to upper byssal threads, about $80 \%$ of the juveniles attached to byssal threads of other individuals. In the Hormomya bed, more than $60 \%$ of juvenile $S$. virgatus attached to the upper shell surfaces of large $H$. mutabilis, the percentage being significantly higher than that for juvenile $S$. virgatus in the Septifer bed (Wilcoxon's signed rank test: $\mathrm{T}=0, \mathrm{n}=24$, $\mathrm{p}<0.01)$. 
Table 2. Mean ( \pm SD) percentage of mussels exposed at the surface of mussel bed. $U$ : result of Mann-Whitney $U$ test. Data from four scraping quadrats in each mussel bed in April 1992.

\begin{tabular}{crcc}
\hline Shell length $(\mathrm{mm})$ & \multicolumn{1}{c}{ S. virgatus } & H. mutabilis & \multicolumn{1}{c}{$\mathrm{U}_{(4.4)}$} \\
\hline $0-$ & $2.8 \pm 2.6$ & $3.4 \pm 4.3$ & $7.0^{\text {ns }}$ \\
$5-$ & $16.6 \pm 2.6$ & $5.9 \pm 4.4$ & $16.0^{*}$ \\
$10-$ & $51.0 \pm 10.9$ & $34.5 \pm 5.2$ & $16.0^{*}$ \\
$15-$ & $90.9 \pm 12.4$ & $100.0 \pm 0.0$ & $12.0^{\text {ns }}$ \\
$20-$ & $100.0 \pm 0.0$ & $100.0 \pm 0.0$ & - \\
$25-$ & $100.0 \pm 0.0$ & - & - \\
$30-$ & $100.0 \pm 0.0$ & - & - \\
\hline
\end{tabular}

*: significant at $5 \%$ level, ${ }^{\text {ns: }}$ : not significant at $5 \%$ level.

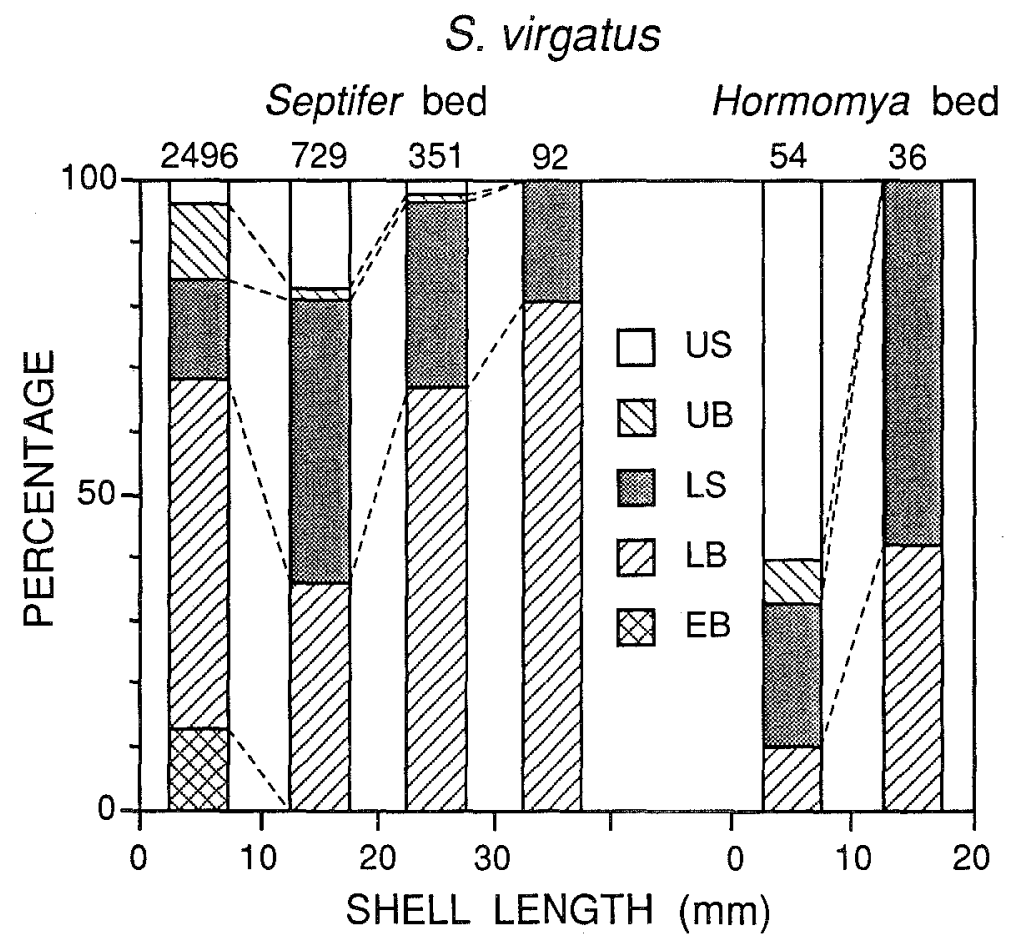

Fig. 7. Attachment locations of $S$. virgatus within mussel beds at site B. A numeral above each histogram indicates the number of mussels examined for each size group throughout the study period. US: upper shell surface, UB: upper byssus, LS: lower shell surface, LB: lower byssus, EB: entangled with byssus, see "Methods" and Fig. 2 for the detail. 
More than half of the small S. virgatus in the Septifer bed attached to upper or lower shell surfaces of large mussels, the percentage (US +LS in Fig. 7) being significantly higher than that in the juvenile mussels $(T=0, n=24, p<0.01)$. However, the percentage (US + LS) decreased with increasing shell length, and very few large mussels attached to the upper shell surfaces of other large mussels. On the other hand, the percentage of mussels attaching to the lower byssal threads of other mussels increased (Fig. 7). As a result S. virgatus never formed multi-layered mussel beds. Small S. virgatus in the Hormomya bed did not attach directly to the rock surface but either to the lower shell surfaces or lower byssal threads of large $H$. mutabilis.

\section{H. mutabilis}

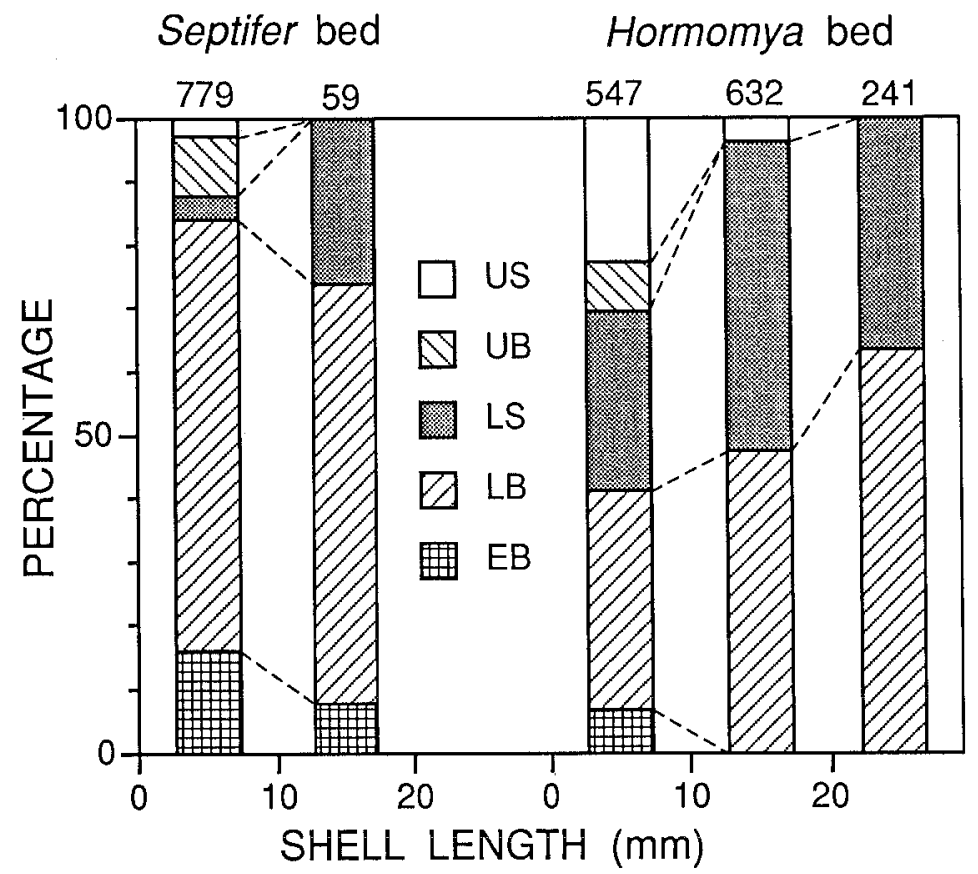

Fig. 8. Attachment locations of $H$. mutabilis within mussel beds at site B. Abbreviations are the same as in Fig. 7.

The attachment locations of $H$. mutabilis also differed considerably between the Septifer and Hormomya beds (Fig. 8). In the Septifer bed, less than $10 \%$ of juvenile $H$. mutabilis attached to the upper or lower shell surfaces of large mussels, while in the Hormomya bed the percentage exceeded $50 \%$. The difference was significant at the $1 \%$ level $(\mathrm{T}=0, \mathrm{n}=24, \mathrm{p}<0.01)$. More than $70 \%$ of juvenile $H$. mutabilis in the Septifer bed attached to the upper or lower byssal threads of other mussels, the percentage being significantly higher than in the Hormomya bed $(T=4, n=24$, $\mathrm{p}<0.01)$. The percentage of small $H$. mutabilis attaching to lower byssal threads of other individuals was more than $60 \%$ in the Septifer bed, being significantly higher 
than that in the Hormomya bed $(\mathrm{T}=0, \mathrm{n}=24, \mathrm{p}<0.01)$. About $50 \%$ of small $H$. mutabilis in the Hormomya bed attached to the lower shell surfaces of other mussels, the percentage being significantly higher than in the Septifer bed $(T=0, n=24$, $\mathrm{p}<0.01)$. The percentages for upper shell surface and upper byssal threads in the Hormomya bed decreased with increasing shell length, resulting in a single-layered mussel bed in $H$. mutabilis as in S. virgatus.

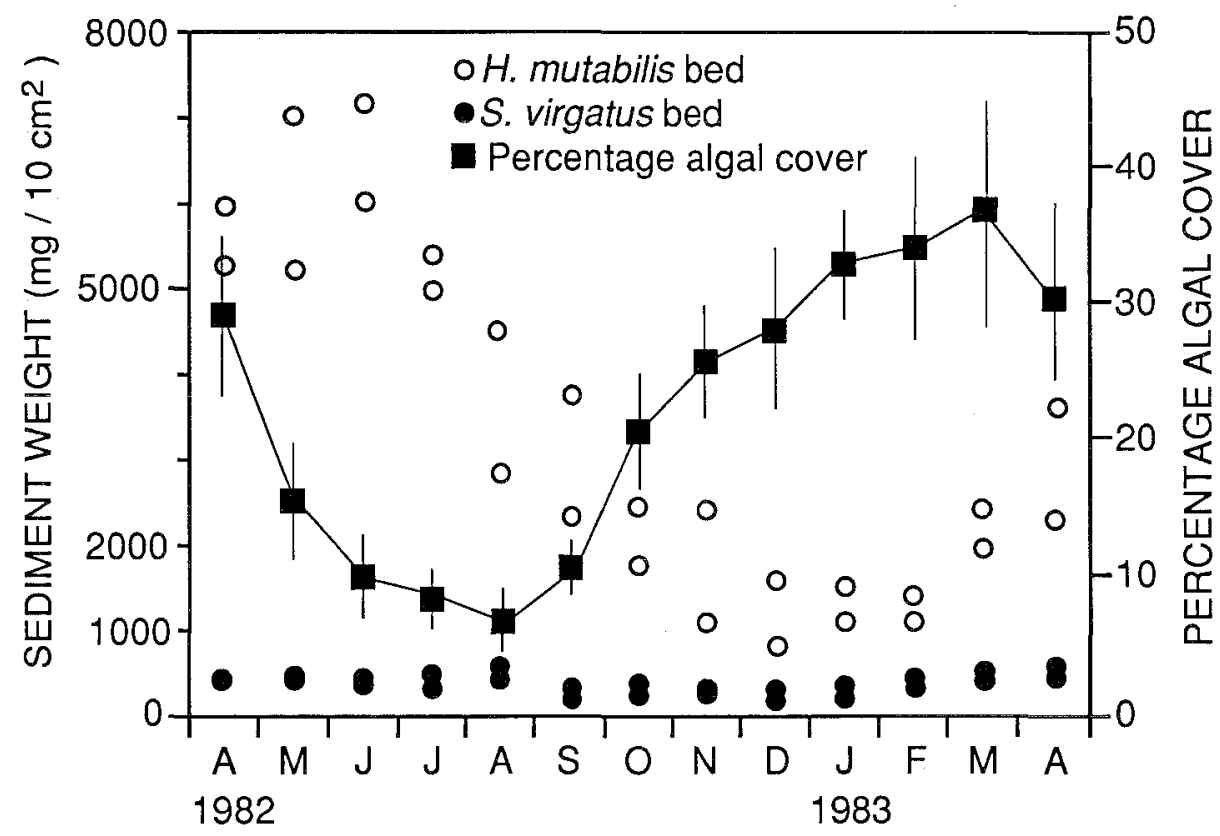

Fig. 9. Monthly change in the sediment weight within mussle beds and mean percentage algal cover ( $\pm \mathrm{SE}$ as a vertical bar) in the $H$. mutabilis bed at site $\mathrm{B}$. Two samples were collected for the sediment every month.

Amount of sediment in mussel beds at site B

The amount of sediment in the Hormomya beds showed remarkable seasonal change (Fig. 9), decreasing from summer to winter and then increasing in spring. On the other hand, the amount in the Septifer bed did not exhibit such a seasonal change, and was much smaller than that in the Hormomya bed (Wilcoxon's signed rank test, $\mathrm{T}=0, \mathrm{n}=26, \mathrm{p}<0.01)$.

Inclination of the Hormomya bed did not differ significantly from that of the Septifer bed (Septifer bed: $5.17^{\circ} \pm 1.09$ SD, Hormomya bed: $4.86^{\circ} \pm 0.83$, one way ANOVA after arcsine transformation, $\left.\mathrm{F}_{(1,38)}=1.215, \mathrm{p}>0.05\right)$. Accordingly, the greater sedimentation in the Hormomya bed cannot be attributed to weaker inclination of the mussel bed. About $20-50 \%$ of the Hormomya bed on the transect at site $\mathrm{B}$ was covered by several foliose algae in April 1982 (Fig. 3) and this algal cover appeared to decrease the wave impact upon the Hormomya bed and to enhance sedimentation in the mussel bed. As shown in Fig. 9, however, seasonal change in 
the mean algal cover did not correspond to the change in the amount of sediment in the Hormomya bed. Conversely, a significant negative correlation was detected between the mean algal cover and the sediment weight $(r=-0.676, n=26, p<0.001)$.
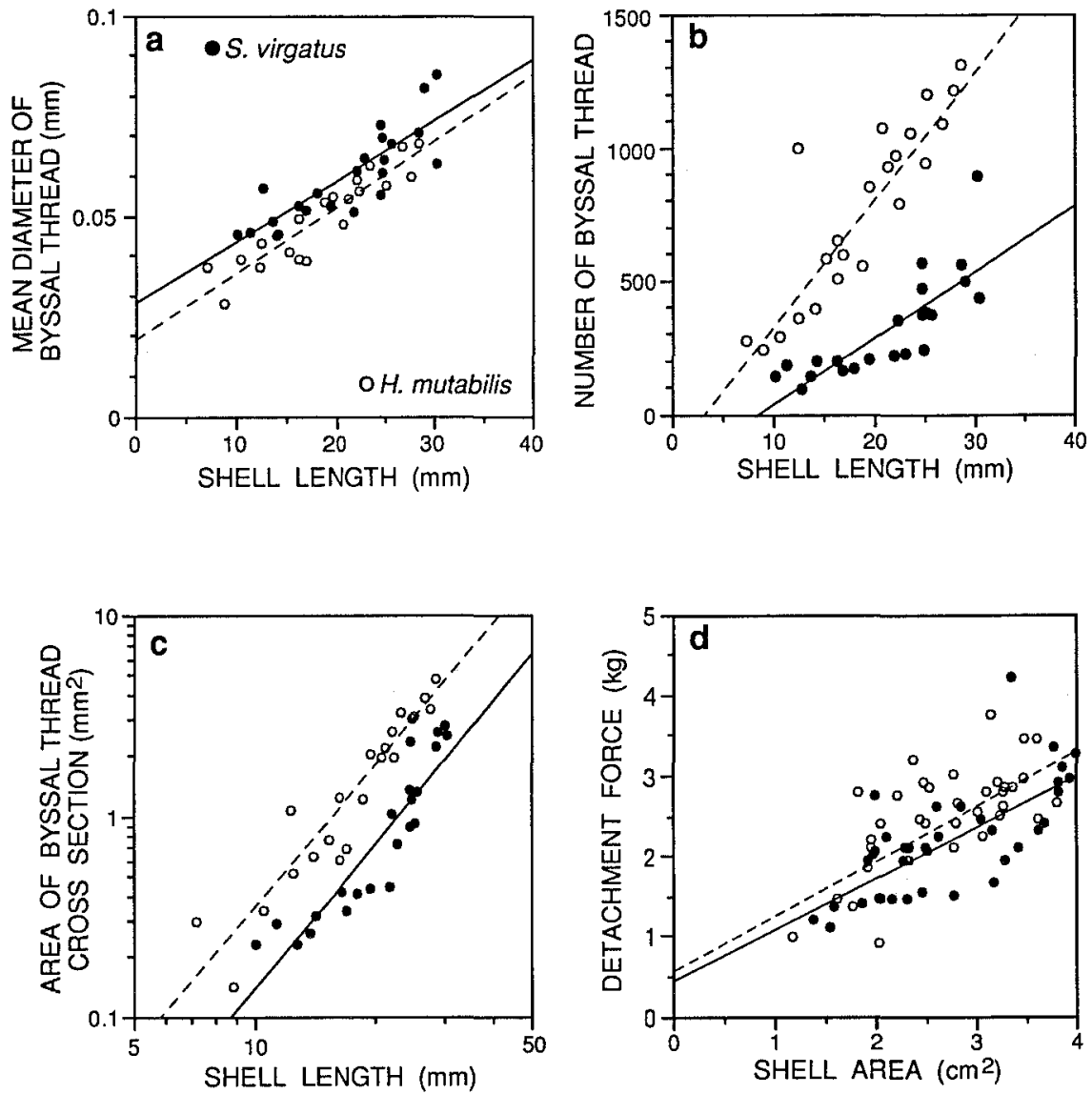

Fig. 10. Relationships between shell length and mean byssal diameter (a), shell length and number of byssal threads (b), shell length and total area of byssus cross section (c) and shell area and required detachment force for both mussel species collected at site $\mathrm{B}(\mathrm{d})$. Solid and broken lines represent regression lines for $S$. virgatus and $H$. mutabilis, respectively. Regression equations for $S$. virgatus: (a) $\mathrm{y}=0.0015 \mathrm{x}+0.028$ $(\mathrm{r}=0.839, \mathrm{df}=20, \mathrm{p}<0.01),(\mathrm{b}) \mathrm{y}=24.73 \mathrm{x}-206.3(\mathrm{r}=0.806, \mathrm{df}=20, \mathrm{p}<0.01)$, (c) $\log (y)=2.396 \log (x)-3.258 \quad(r=0.912, \quad d f=20, \quad p<0.01), \quad(d) \quad y=0.634 x+0.458$ $(\mathrm{r}=0.717, \mathrm{df}=35, \mathrm{p}<0.01)$. Regression equations for H. mutabilis: (a) $\mathrm{y}=0.0017 \mathrm{x}+$ $0.019(\mathrm{r}=0.920, \mathrm{df}=20, \mathrm{p}<0.01)$, (b) $\mathrm{y}=47.63 \mathrm{x}-126.7(\mathrm{r}=0.880, \mathrm{df}=20, \mathrm{p}<0.01)$, 8c) $\log (y)=2.358 \log (x)-2.834 \quad(r=0.938, d f=20, p<0.01),(d) y=0.682 x+0.629$ $(\mathrm{r}=0.69 \mathrm{i}, \mathrm{df}=39, \mathrm{p}<0.0 \mathrm{~L})$.

Amount of byssal threads and force required to detach mussels

The diameter of byssal threads increased with increasing shell length in both species (Fig. 10a). The regression line of thread diameter against shell length for $S$. virgatus lies significantly higher than that for $H$. mutabilis (homogeneity of variance: 
$F_{(21,21)}=1.948, \quad p>0.05 ;$ slope: $F_{(1,40)}=1.40, \quad p>0.05 ;$ elevation: $F_{(1,41)}=10.06$, $\mathrm{p}<0.001$ ), indicating that the byssal threads are significantly thicker in $S$. virgatus than in $H$. mutabilis. The number of threads in a byssus also increased with increasing shell length (Fig. 10b). As the slope of the regression line of the thread number to shell length for $H$. mutabilis was significantly greater than that for $S$. virgatus (variance: $F_{(21,21)}=1.989, p>0.05$; slope: $\left.F_{(1,40)}=10.63, p<0.01\right)$, the line elevation could not be compared statistically between the two species. However, the thread number of H. mutabilis was evidently two or three times greater than that for S. virgatus of the same size (Fig. 10b). It can thus be said that the byssal threads of $H$. mutabilis were more slender but more numerous than those of $S$. virgalus.

Total area of cross sections of the threads in a byssus can be estimated from mean thread diameter and thread number, assuming that the threads are circular. The area was again correlated positively with shell length for both species (Fig. 10c). The elevation of the regression line for $H$. mutabilis was higher than that for $S$. virgatus (variance: $F_{(21,21)}=1.191, p>0.05$; slope: $F_{(1,40)}=0.02, p>0.05$; elevation: $F_{(1,41)}=$ $65.86, \mathrm{p}<0.01)$. The force required to detach a mussel was positively correlated with approximate shell size (= shell length $\times$ shell height) (Fig. 10d). Elevation of the regression line for $H$. mutabilis was also higher than that for $S$. virgatus (variance: $F_{(34,39)}=1.144, \quad p>0.05 ;$ slope: $F_{(1,73)}=0.09, \quad p>0.05 ;$ elevation: $F_{(1,74)}=7.78$, $\mathrm{p}<0.01)$. These facts clearly indicate that the amount of byssal thread material was greater in $H$. mutabilis than in $S$. virgatus and that the strength of attachment to the substratum was also greater in the former than in the latter.

Individual variation in shell shape

Mean variance in the regression of shell height against shell length was significantly greater in $H$. mutabilis than in S. virgatus (Table 3). Mean variance for regression of shell width against shell length was also significantly greater in the former. The

Table 3. Mean variances of observed samples in the regressions of shell height against shell length and of shell width against shell length for 60 individuals of each mussel species with $10-30 \mathrm{~mm}$ shell length. Data from two scraping quadrats in monthly sampling from July 1982 to April 1983. F(df): result of one-way ANOVA after arcsine transformation and the degree of freedom.

\begin{tabular}{lccccc}
\hline \multirow{2}{*}{ Species } & \multicolumn{2}{c}{ Length-Height } & & \multicolumn{2}{c}{ Length-Width } \\
\cline { 2 - 3 } & Mean & SD & & Mean & SD \\
\hline S. virgatus & 0.353 & 0.091 & & 0.383 & 0.181 \\
H. mutabilis & 0.643 & 0.335 & & 1.234 & 0.622 \\
F $(\mathrm{d} f)$ & 13.38 & $(1,38)$ & & 32.94 & $(1,38)$ \\
P & 0.0008 & & 0.0001 & \\
\hline
\end{tabular}


difference in the mean variance between the two species was greater in the shell length-shell width relationship than in the shell length-shell height relationship. Variation in shell shape among individuals was much greater in $H$. mutabilis than in $S$. virgatus, particularly in the shell length-shell width relationship.

\section{Discussion}

Difference in the amount of byssal threads and drag force required to detach mussels

Variation in the amount of byssal thread production in relation to water agitation has been studied for several mussel species. Harger (1970c) found that Mytilus californianus dwelling on wave-exposed shores had more abundant and thicker threads than $M$. edulis dwelling on wave-sheltered ones. He also reported that the drag force required to detach mussels was greater in $M$. californianus than in $M$. edulis. Glaus (1968) and Young (1985) revealed that the number of threads of $M$. edulis increased with increased water agitation in the laboratory, though Van Winkle (1970) reported a decrease in byssus formation with excessive agitation for Modiolus demissus. All these authors, and many other researchers on byssal thread production and on the strength of mussel attachment (Allen et al., 1976; Price, 1980, 1982; Smeathers \& Vincent, 1979; Witman \& Suchanek, 1984; Denny, 1987; Meadows \& Shand, 1989), have supposed that the increase in the amount of byssal thread material results in an increase in the strength of attachment to the substratum.

In the present study also, a positive correlation between the thread amount and the drag force required to detach mussels was detected between the two species (Fig. 10). Howerver, H. mutabilis with a larger amount of thread material and a greater force of attachment to the substratum inhabited less wave-exposed shores than $S$. virgatus (Fig. 1). Moreover, even on a rocky shore where they occur together, $H$. mutabilis appears to receive less intense wave action than $S$. virgatus because wave action becomes weaker towards the lower intertidal zone (e.g. Harger, 1970c). These findings are inconsistent with those of Harger (1970c), Glaus (1968) and Young (1985) mentioned above. Thus the interspecific difference between $S$. virgatus and $H$. mutabilis cannot be attributed to an adaptive response to the degree of wave action in their habitats. Responses to some other ecological, physiological or environmental factor(s) may have created the difference, and the relationship between the byssal thread production and sedimentation is discussed in a following section.

Variability in shell shape among individuals

Seed (1968), comparing shell shape of $M$. edulis collected from several localities and used in transplantation experiments, found that the shell shape was greatly influenced by growth rate and density through physical compression. According to the author's findings, high compression leads to an elongate form, and low compression to higher, more triangular shells. 'The increase in shell width is not greatly affected by the physical compression. He also suggested that wide variation is to be expected 
even in mussels from the same locality.

In the present study, shell shape of $H$. mutailis (measured as shell length-shell height and shell length-shell width relationships) varied among individuals collected even within a $5 \times 10 \mathrm{~cm}^{2}$ quadrat, and the variation especially in shell width, was greater than that of $S$. virgatus (Table 3 ). However, no significant difference in the density of small and large mussels was detected between the two species (Table 1. Density of juvenile mussels is not worth consideration in this argument since density appears to exert no effect on the degree of physical compression within mussel beds because of their small sizes.). Thus the interspecific difference in shell shape variability cannot be ascribed to a difference in mussel density in respective beds. It can be said that $H$. mutabilis has a more plastic shell shape than $S$. virgatus in situations of a similar mussel density.

Cause of accumulation of sediment in the Hormomya bed

Biodeposition of faeces and pseudofaeces and sedimentation of sand, silt and mud within natural mussel beds have been reported by many investigators (e.g.Tsuchiya, 1979; Tsuchiya \& Nishihira, 1985, 1986; Kautsky \& Evans, 1987). In the present study, the Hormomya bed had a larger amount of sediment than the Septifer bed and the amount in the Hormomya bed exhibited remarkable seasonal change (Fig. 9). The exact causes of the interspecific difference and the seasonal change in the Hormomya bed were not determined in the present study. As mentioned before, the difference cannot be attributed to the presence of algal cover in the Hormomya bed nor to the difference in mussel bed inclination. Conversely, the inverse correlation between the precentage algal cover and the amount of sediment in the Hormomya bed may indicate some negative effect of algal cover on the accumulation of sediment.

Two possible causes for the difference in the amount of sediment are indicated by interspecific differences in mussel morphology. One is the difference in the number of byssal threads. Bertness (1984) demonstrated that the ribbed mussel Geukensia demissa trapped and bound sediment at salt marsh edges and stabilized the substrata with a strong network of byssal threads. The greater amount of byssal threads in the Hormomya bed may have trapped more particles drifting in the water (Fig. 11).

The other is the difference in individual variability in shell shape. The shell shape of $H$. mutabilis is more plastic than that of $S$. virgatus. This plasticity may permit $H$. mutabilis to fill up the gaps between adjacent large mussels, producing more tightly packed mussel beds (Fig. 11). This may reduce the penetration of waves into the beds and facilitate sedimentation. Further experimental study is needed to clarify the exact cause of the accumulation.

Difference in the attachment location within mussel beds

Seveal investigators reported that initial settlement of mussel larvae occurs preferentially on filamentous substrata such as bryozoans, hydroids and filamentous algae (Bayne, 1964, 1976; Seed, 1969; Petersen, 1984a, b; Eyster \& Pechenik, 1987). After metamorphosis on such substrata, the plantigrades move onto byssal 

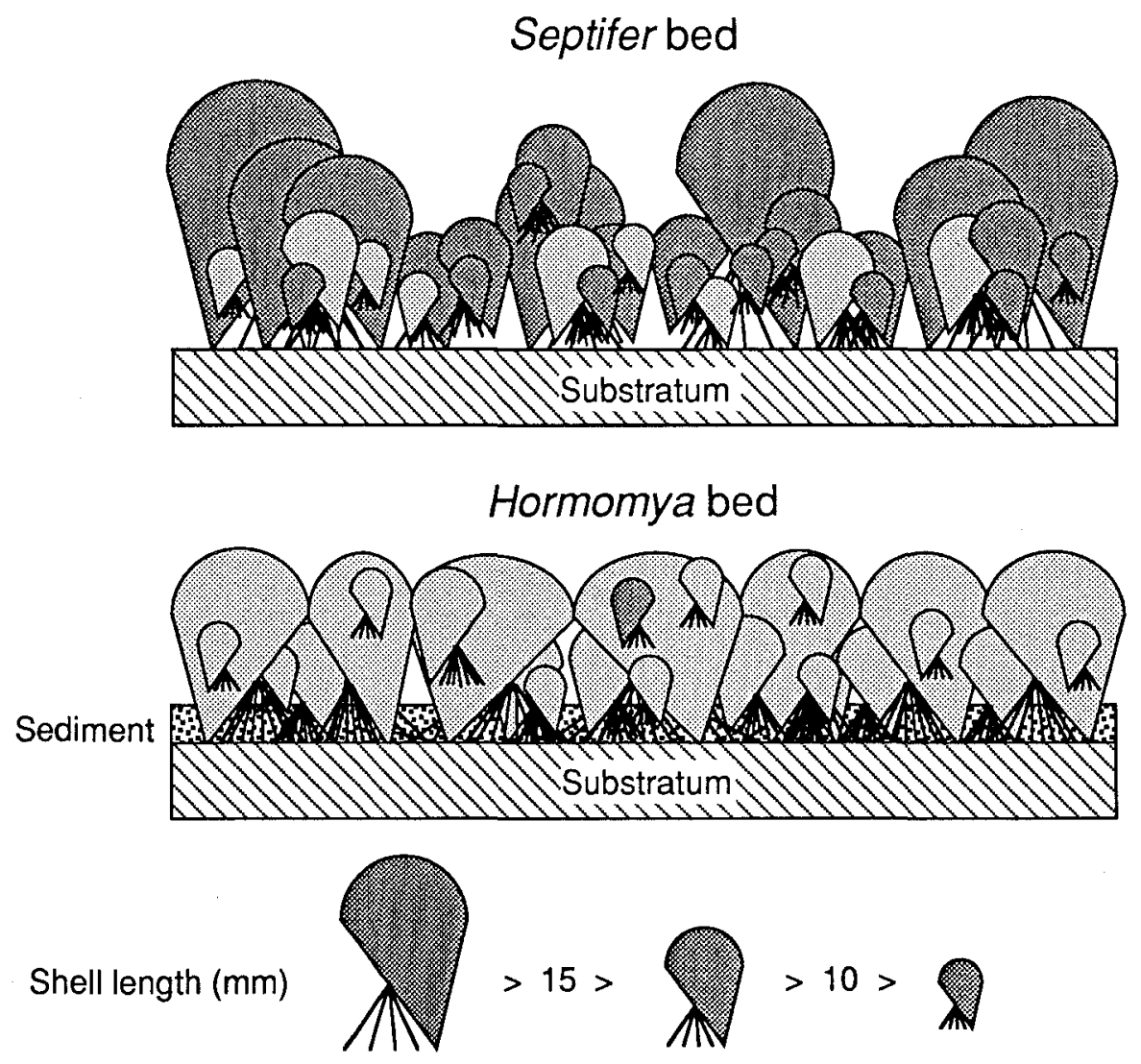

Fig. 11. Schematic representation of mussel bed structure at site B.

threads of adult mussels (Bayne, 1964) by drifting with a single, long byssal thread (Sigurdsson, 1976; Lane et al., 1985). Direct settlement of $M$. edulis larvae onto byssal threads of adult mussels has also been reported recently (McGrath et al., 1988). Moreover $M$. edulis larvae are known to avoid settling on adult patches of $M$. californianus and preferentially settle on large conspecifics or filamentous alga in laboratory experiments (Petersen, 1984a, b). As for S. virgatus and H. mutabilis, no information on primary and secondary settlement is available until now.

The present study has shown marked differences in the number and attachment locations of juvenile $S$. virgatus between Septifer and Hormomya beds (Figs. 4 and 7). These results suggest preferential settlement on the byssal threads of large conspecifics in the Septifer bed and avoidance of settlement on the threads of $H$. mutabilis in the Hormomya bed. However, when large $S$. virgatus and $H$. mutabilis were translocated into both Hormomya and Septifer beds using enclosure cages, many juvenile $S$. virgatus were found attached to the byssal threads of large mussels of both species (Iwasaki, in preparation). Results of these experiments indicate that juvenile $S$. virgatus do not avoid attaching directly to the byssal threads of large $H$. 
mutabilis.

The most remarkable difference between the mussel beds of the two species was found in the amount of sediment. Branch \& Barkai (1988) and Barkai \& Branch (1989) reported an interspecific difference in the tolerance of smothering by siltation between two mussel species. Harge (1968, 1972a) demonstrated that bay mussels, $M$. edulis, are more tolerant of silting and less susceptible to smothering in quiet waters than the wave-exposed species $M$. californianus. Results from the present study (Fig. 8) also indicate greater tolerance of smothering by sedimentation in juvenile $H$. mutabilis than in $S$. virgatus, because many jevenile $H$. mutabilis attached to the lower part of the Hormomya bed while only a few juvenile $S$. virgatus attached to the upper part. Inside the Hormomya bed, predatory polychaetes such a Arabella iricolor (Montagu) were found at higher densities than in the Septifer bed (Ohsako et al., 1982a; Iwasaki, in preparation). To detect the effects of the predators on mussel abundance, artificial. S. virgatus and $H$. mutabilis clumps were created separately and exposed to the predators from the Hormomya bed (Iwasaki, in prepartion). The clumps survived for at least a year and many juvenile $S$. virgatus were found settling in the artificial clumps. Thus the predators appear to have exerted no serious effect. It is thus suggested that the very low density of juvenile $S$. virgatus in the Hormomya beds is due to the presence of sediment inhibiting the settlement or survial of $S$. virgatus larvae or plantigrades.

Factors affecting the lower limit of $S$. virgatus at site $\mathrm{B}$

It has long been believed that vertical distributions of intertidal organisms are higher on exposed shores than on sheltered ones (e.g., Mokyevksy, 1960; Lewis, 1961; Tsuchiya, 1979). Also, in the present study sites, where wave action decreased in the order of sites A, B and C (for the sites B and C, see Ohsako et al., 1981), lower distribution limits of two barnacle species, C. challengeri and T. s. japonica, were higher at site $\mathrm{A}$ than at site $\mathrm{B}$, and the upper limit of $H$. mutabilis was higher at site $\mathrm{B}$ than at site G (Fig. 3). Nevertheless, the lower distribution limit of S. virgatus at site A was lower than that at site B. Moreover, the Septifer bed at site B was replaced abruptly by the Hormomya bed (Fig. 3), and the density of even small $S$. virgatus was very low in the Hormomya bed (Figs. 4 and 5). No dead shells of juvenile $S$. virgatus were found within the Hormomya bed (personal observation).

Several investigators have reported the presence of strong predators which affect the lower limit or the horizontal distribution of mussels (Paine, 1974; Griffiths \& Seiderer, 1980; Branch \& Barkai, 1988; Barkai \& Branch, 1989). In the present study sites, however, no such strong predators influencing the mussel distribution were found either inside or outside the mussel beds (Iwasaki, personal observation). These facts strongly suggest that the lower limit of the Septifer bed was determined by detrimental effect(s) exerted in the Hormomya bed, not during the post larval growing period, but at the settlement stage of $S$. virgatus larvae or plantigrades. As mentioned in the preceding section, presence of a large quantity of sediment in the Hormomya bed must have prevented $S$. virgatus from settling on the byssal threads of $H$. mutabilis. 
Factors affecting the upper limit of $H$. mutabilis at site $B$

As shown in Table 2, most $S$. virgatus larger than $15 \mathrm{~mm}$ long were exposed at the surface of the Septifer bed. In other words, mussels became exposed as they grew larger than about $15 \mathrm{~mm}$. Relative humidity outside the bed was much lower than that within mussel beds during daytime at site B (Ohsako et al., 1981). Thus, not only $S$. virgatus but also $H$. mutabilis in the Septifer bed must have experienced more severe desiccation as they grew larger than about $15 \mathrm{~mm}$. As described before, densities of putative predators upon mussels were significantly lower in the Septifer bed than in the Hormomya bed (Ohsako et al., 1982a; Iwasaki, in preparation), and there were no predators preying preferentially upon $H$. mutabilis larger than $15 \mathrm{~mm}$ (Iwasaki, personal observation). Accordingly the absence of large $H$. mutabilis in the Septifer bed (Figs. 4 and 6) may be explained by their death from desiccation. In other words, the upper limit of the Hormomya bed is determined by physiological stress due to desiccation exceeding its tolerance limit.

However, juvenile and small mussels occurred above the upper limit of large conspecifics. In the upper and mid intertidal zones at site $\mathrm{C}$, where the patellid limpet $P$. saccharina lanx and two barnacle species were abundant (Fig. 3), no $H$. mutabilis were found on the rock surface nor among the barnacle stands. Thus the presence of the Septifer bed at site B may have provided the juvenile and small $H$. mutabilis with refuge from desiccation as Van Erkom Schurink \& Griffiths (1990) report for two South African mussels, Mytilus galloprovincialis and Aulacomya ater.

The review by Suchanek (1985) on the limiting factors of mussel vertical distribution supports the speculation of Connell (1961a, b) that upper and lower limits of barnacles and other intertidal organisms are controlled by physiological stress and interspecific interactions, respectively. However, the situation in the present study may be more complex because the upper limit of juvenile and small $H$. mutabilis was different from that of large ones. Several investigators of distributions of intertidal organisms have identified or suggested limiting factors inconsistent with this speculation (Hoshiai, 1964; Ross \& Goodman, 1974; Choat, 1977; Underwood, 1980; Underwood \& Jernakoff, 1981; Yipp \& Carefoot, 1988; Iwasaki, 1993). Moreover, Underwood \& Denley (1984) cast doubt on the generalization of the schemes proposed by Connell (1961a, b) for intertidal organisms. Experimental study is essential to ascertain the factors determining the upper or lower limit of the two mussel species considered in the present study.

\section{Acknowledgements}

I am decply grateful to Naoya Abe, Eiji Harada, Graham G. Kearn, Kensuke Nakata, Shun-ichi Ohgaki, Misako Urabe, Keiji Wada, Takeshi Wada, and Tomoko Yamamoto for critical readings of the manuscript or correction of English. I am also indebted to the members of the Laboratory of Animal Ecology, Kyoto University for their kind advice during the field study. 


\section{References}

Allen, J.A., M. Cook, D.J. Jackson, S. Preston \& E.M. Worth. 1976. Observations on the rate of production and mechanical properties of the byssus threads of Mytilus edulis L. J. Moll. Stud., 42: 279-289.

Barkai, A. \& G.M. Branch. 1989. Growth and mortality of the mussels Choromyitilus meridionalis (Krauss) and Aulacomya ater (Molina) as indicators of biotic conditions. J. Moll. Stud., 55: 329-342.

Bayne, B.L. 1964. Primary and secondary settlement in Mytilus edulis L. (Mollusca). J. Anim. Ecol., 33: 513-523.

_. 1976. The biology of mussel larvae. In: B.L. Bayne (ed.), Marine Mussels: Their Ecology and Physiology, pp. 81-120. Cambridge University Press, Cambridge.

Bertness, M.D. 1984, Ribbed mussels and Spartina alterniflora production in a New England salt marsh. Ecology, 65: 1794-1807.

\& E. Grosholz. 1986. Population dynamics of the ribbed mussel, Geukensia demissa: the costs and benefits of an aggregated distribution. Oecologia (Berl.), 67: 192-204.

Branch, G.M. \& A. Barkai. 1988. Interspecific behaviour and its reciprocal interation with evolution, population dynamics and community structure. In: M. Vannini \& G. Chelazzi (eds.), Behavioral Adaptation to Intertidal Life, pp. 225-254. Plenum Press, New York.

Choat, J.H. 1977. The influence of sessile organsims on the population biology of three species of acmaeid limpets. J. Exp. Mar. Biol. Ecol., 26: 1-26.

Connell, J.H. 1961a. The influence of interspecific competition and other factors on the distribution of the barnacle Chthamalus stellatus. Ecology, 42: 710-723.

. $196 \mathrm{lb}$. Effects of competition, predation by Thais lapillus and other factors on natural populations of the barnacle Balanus balanoides. Ecol. Monogr., 31: 61-104.

Denny, M.W. 1987. Life as a mechanism of patch initiation in mussel beds. J. Exp. Mar. Biol. Ecol., 113: $231-245$

Eyster, L.S. \& J.A. Pechenik. 1987. Attachment of Mytilus edulis L. larvae on algal and byssal filaments is enhanced by water agitation. J. Exp. Mar. Biol. Ecol., 114: 99-110.

Glaus, K.J. 1968. Factors influencing the production of byssus threads in Mytilus edulis. Biol. Bull., I35: 420.

Griffiths, C.L. \& J.L. Seiderer. 1980. Rock lobsters and mussels; limitations and preferences in a predator-prey interaction. J. Exp. Mar. Biol. Ecol., 44: 95-109.

Harger, J.R.E. 1968. The role of behavioral traits in influencing the distribution of two species of sea mussels, Mytilus edulis and Mytilus californianus. Veliger, 11: 45-49.

- 1970a. Comparisons among growth characteristics of two species of sea mussels, Mytilus edulis and Mytilus californianus. Veliger, 13: 44-56.

. 1970b. The effects of species composition on the survival of mixed populations of the sea mussels, Mytilus edulis and Mytilus californianus. Veliger, 13: 147-152.

-1970c. The effects of wave impact on some aspects of the biology of sea mussels. Veliger, 13: $401-414$.

1972a. Variation and relative "niche" size in the sea mussel Mytilus edulis in association with Mytilus californianus. Veliger, 14: 275-283.

. 1972b. Competitive co-existence: maintenance of interacting associations of the sea mussel Mytilus edulis and Mytilus californianus. Veliger, 14:387-410.

— D.E. Landenberger. 1971. The effects of storms as a density dependent mortality factor on populations of sea mussels. Veliger, 14: 195-201.

Hoshiai, T. 1958. Synecological study on intertidal communities. I. The zonation of intertidal animal community with special reference to the interspecific relation. Bull. Mar. Biol. St. Asamushi, Tohoku Univ., 9: 27-33.

-1961. Synecological study on intertidal communities II. An ecological investigation on the zonation in Matsushima Bay concerning the so-called covering phenomenon. Bull. Mar. Biol. St. Asamushi, Tohoku Univ., 10: 203-211.

- 1964. Synecological study on intertidal communities. V. The interrelation between Septifer virgatus and Mytilus edulis. Bull. Mar. Biol. St. Asamushi, Tohoku Univ., 12: 37-41.

Hosomi, A. 1987. On the density effect in populations of the mussel, Mytilus galloprovincialis. Venus (Jap. J. Malac.), 46: 116-126.

- 1989. Murasaki-igai No Seitaigaku (The Ecology of Mytilus galloprovincialis Lamarck). 
Sankaido, Tokyo, 137pp. (in Japanese).

Iwasaki, K. 1993. The role of individual variability in limpet resting site fidelity and competitive ability in the organization of a local rocky intertidal community. Physiol. Ecol. Japan, 30: 31-70.

Jackson, J.B.C. 1983. Biological determinants of present and past sessile animal distributions. In: M.J.S. Tevesz \& P.C. McCall (eds.), Biological Interactions in Recent and Fossil Benthic Communities, pp. 39-120, Plenum Press, New York.

Kautsky, N. \& S. Evans. 1987. Role of biodeposition by Myitus edulis in the circulation of matter and nutrients in a Baltic coastal ecosystem. Mar. Ecol. Prog. Ser., 38: 201-212.

Kennedy, V.S. 1976. Desiccation, high temperature and upper intertidal limits of three species of sea mussels (Mollusca: Bivalvia) in New Zealand. Mar. Biol., 35: 127-137.

Lane, D.J.W., A.R. Beaumont \& J.R. Hunter. 1985. Byssus drifting and the drifting threads of the young post-larval Mytilus edulis. Mar. Biol., 84: 301-308.

Lewis, J.R. 1961. The littoral zone on rocky shores-a biological or physical entity? Oikos, 12: 280-301.

McGrath, D., P.A. King \& E.M. Gosling. 1988. Evidence for the direct settlement of Mytilus edulis larvae on adult mussel beds. Mar. Ecol. Prog. Ser., 47: 103-106.

Meadows, P.S. \& P. Shand. 1989. Experimental analysis of byssus thread production by Mytilus edulis and Modiolus modiolus in sediments. Mar. Biol., 101: 219-226.

Mokyevsky, D.B. 1960. Geographical zonation of marine littoral type. Limnol. Oceanogr., 5: 389-396.

Ohsako, Y,, K. Iwasaki, S. Sakimukai, T. Fukutomi \& K.Satake. 1981. An example of the distribution of organisms in intertidal zone near the Seto Marine Biological Laboratory of Kyoto University. I. Nankiseibutsu, 23: 97-102. (in Japanese).

An example of the distribution of organisms 24: 47-52. (in Japanese).

,, \& $\longrightarrow$ 1982b. An example of the distribution of organisms in intertidal zone near the Seto Marine Biological Laboratory of Kyoto University. III. Nankiseibutsu, 24: 107-113. (in Japanese).

Okamura, B. 1986. Group living and the effects of spatial position in aggregation of Mytilus edulis. Oecologia (Berl.), 69: 341-347.

Paine, R.T. 1974. Intertidal community structure: experimental studies on the relationship between a dominant competitor and principal predator. Oecologia (Berl.), 15: 93-120.

Petersen, J.H. 1984a. Establishment of mussel beds: attachment behavior and distribution of recently settled mussels (Mytilus californianus). Veliger, 27: 7-13.

- 1984b. Larval settlement behavior in competing species: Mytilus californianus Conrad and $M$. edulis L. J. Exp. Mar. Biol. Ecol., 82: 147-159.

Price, H.A. 1980. Seasonal variation in the strength of byssal attachment of the common mussel, Mytilus edulis L. J. mar. biol. Ass. U.K., 60: 1035-1037.

-1982. An analysis of factors determining seasonal variation in the byssal attachment strength of Mytilus edulis. J. mar. biol. Ass. U.K., 62: 147-155.

Ross, J.R.P. \& D. Goodman. 1974. Vertical intertidal distribution of Mytilus edulis. Veliger, 16:388-395.

Safriel, U.N. \& Z. Sasson-Frostig. 1988. Can colonizing mussel outcompete indigenous mussel? J. Exp. Mar. Biol. Ecol., 117: 211-226.

Seed, R. 1968. Factors influencing shell shape in the mussel Mytilus edulis. J. mar. biol. Ass. U.K., 48: 561-584.

- 1969. The ecology of Mytilus edulis L. (Lamellibranchiata) on exposed rocky shores. I. Breeding and settlement. Oecologia (Berl.), 3: 277-316.

1976. Ecology. In: B.L. Bayne (ed.), Marine Mussels, Their Ecology and Physiology, pp. 13-66. Cambridge University Press, Cambridge.

- \& Suchanek, T.H. 1992. Population and community ecology of Mytilus. Dev. Aqua. Cult. Fish. Sci., 25: 87-169.

Sigurdsson, J.B. 1976. The dispersal of young post-larval bivalve molluscs by byssus threads. Nature, 262: $386-387$.

Smeathers, J.E. \& J.F.V. Vincent. 1979. Mechanical properties of mussel byssus threads. J. Moll. Stud., 45: 219-230.

Sokal, R.R. \& F.J. Rohlf. 1981. Biometry, second edition. W.H. Freeman and Company, New York, 859 pp. 
Suchanek, T.H. 1978. The ecology of Mytilus edulis in exposed rocky intertidal communities. J. Exp. Mar. Biol. Ecol., 31: 105-120.

1981. The role of disturbance in the evolution of life history strategies in the intertidal mussels Mytilus edulis and Mytilus californianus. Oecologia (Berl.), 50: 143-152.

1985. Mussels and their role in structuring rocky shore communities. In: P.G. Moore \& R. Seed (eds.), The Ecology of Rocky Coasts, pp. 70-96. Hodder and Stoughton, London.

Tsuchiya, M. 1979. Quantitative sruvey of intertidal organisms on rocky shores in Mutsu Bay, with special reference to the influence of wave action. Bull. Mar. Biol. St. Asamushi, Tohoku Univ,, 16: 69-86.

_._. \& M. Nishihira. 1985. Islands of Mytilus edulis as a habitat for small intertidal animals: effect of island size on community structure. Mar. Ecol. Prog. Ser., 25: 71-81.

- \& 1986. Islands of Mytilus edulis as a habitat for small intertidal animals: effects of Mytilus age structure on the species composition of the associated fauna and community organization. Mar. Ecol. Prog. Ser., 31: 171-178.

Underwood, A.J. 1980. The effects of grazing by gastropods and physical factors on the upper limits of disribution of intertidal macroalgae. Oecologia (Berl.), 46: 201-213.

\& E.J. Denley. 1984. Paradigms, explanations and generalizations in models for the structure of intertidal communities on rocky shores. In: D.R. Strong Jr., D. Simberloff, L.G. Abele \& A.B. Thistle (eds.), Ecological Communities: Conceptual Issues and the Evidence, pp. 151-180. Princeton University Press, New Jersey.

- \& P. Jernakoff. 1981. Effects of interactions between algae and grazing gastropods on the mid-shore rocky intertidal communities in New South Wales. Oecologia (Berl.), 48: 221-233.

Van Erkom Schurink, C. \& C.L. Griffiths. 1990. Marine mussels of Southern Africa: their distribution patterns, standing stocks, exploitation and culture. J. Shellfish Res., 9: 75-85.

Van Winkle, W., Jr. 1970. Effects of environmental factors on byssal threads formation. Mar. Biol., 7: 143-148.

Witman, J.D. 1987. Subtidal coexistence: storms, grazing, mutualism, and the zonation of kelps and mussels. Ecol. Monogr., 57: 167-187.

\& T.H. Suchanek. 1984. Mussels in flow: drag and dislodgement by epizoans. Mar. Ecol. Prog. Ser., 16: 259-268.

Yipp, M.W. \& T.H. Carefoot. 1988. Studies on distribution, degree of aerial exposure, and competitive interactions in four species of tropical intertidal gastropods. Veliger, 31: 91-100.

Young, G.A. 1985. Byssus-threads formation by the mussel Mytilus edulis: effects of environmental factors. Mar. Ecol. Prog. Ser., 24: 261-271. 